\title{
Management Model and the Success Factors of Village Owned Enterprises (VOEs) in Indonesia
}

\author{
Submitted 25/02/21, $1^{\text {st }}$ revision 28/03/21, $2^{\text {nd }}$ revision 09/04/21, accepted 25/05/21
}

\author{
Jamal Bake ${ }^{1}$, Haedar Akib ${ }^{2}$, Risma Niswaty ${ }^{3}$
}

\begin{abstract}
:
Purpose: This study aims to describe and analyze the development management model of Village-Owned Enterprises (VOEs) and identify and explain the determining factors for the success of VOEs in Indonesia.

Design/Methodology/Approach: The study approach used qualitative methods, document studies, publications on VOEs performance, secondary data, field observations, and interviews with several sources.

Findings: The study results explain three models found in the development of VOEs, namely an ambiguous model, a subjective approach, and a cultural management model.

Practical Implications: The determinants of VOEs development are organizational factors in the form of human resources (HR), leadership, technology support, organizational culture, financial governance, institutional arrangement. Meanwhile, contextual factors (outside the organization) are government intervention, raw materials and production technology, accessibility, market opportunities, economic and socio-cultural conditions, demographics, physical environment, and policies.

Originality/Value: Triangular prototype model of determinants of success of Village-Owned Enterprises (VOEs)
\end{abstract}

Keywords: Management model, the determinant factor of success, village-owned enterprises.

JEL classification: L23, L32, M13, O35, O43, O53.

Paper Type: Research Paper.

Acknowledgements: Work by the authors were funded and supported by the Non-Tax Income Fund for the Professor's Acceleration Program, Universitas Halu Oleo.

\footnotetext{
${ }^{1}$ Associate Professor, Researchers and Lecturers at the Department of Administrative Sciences, Universitas Halu Oleo, Indonesia, elsikapi2002@yahoo.com;

${ }^{2}$ Professor, Head of the Department of Administrative Science, Universitas Negeri Makassar, Indonesia, haedarakib@unm.ac.id;

${ }^{3}$ Associate Professor, Head of Public Administration Master Program, Universitas Negeri Makassar, Indonesia, rismaniswaty313@gmail.com;
} 


\section{Introduction}

Village-owned enterprises (VOEs) are formal economic institutions as companies formed by the village government (Mania, Arasb, and Hidayatc, 2020; Muluk, 2020; Ridlwan, 2014; Sari, 2019). This institution was formed to accelerate the realization of an independent, rural-based people's economy. The drive to develop VOEs in a professional and controlled manner is strengthened through Law Number 06 of 2014 concerning Villages (Ministry of Home Affairs Republik Indonesia, 2014). Previously, it was regulated in Government Regulation Number 72 of 2005 concerning the establishment, management, management, and dissolution of VOEs (Directorate General of Rural Areas Development, Ministry of Villages, Disadvantaged Regions, 2017). The operational foundation is stipulated, among others, by the Regulation of the Minister of Villages and Development of Disadvantaged and Isolated Areas Number 4 of 2015 concerning Management of VOEs, as well as the Regulation of the Minister of Villages Number 11 of 2019 concerning Priority for the Use of Village Funds which, among others, confirms the development of village-owned companies using village funds sourced from central government transfers.

The principal capital for VOEs development comes from the village government through capital from the State Revenue Budget, which is allocated through the village income and expenditure budget (Iriani, Andjarwati, and Rahman, 2020; Sari, 2019; Srirejeki, 2018). Through the VOE, the village government develops people's economic potential, provides services to meet the needs of residents, explores the potential for commodities and products that have export opportunities to gain profit and increase the village's original income. Even though the capital comes from state funds, its management has a spirit of independence, togetherness, and cooperation involving the village government and its people. According to Iriani et al. (2020), VOE is a rural business managed collectively through a partnership between the village government and the community in a more inclusive manner than the management model of cooperatives, private businesses, and other businesses operating in the village.

The uniqueness of VOE, according to experts (Muluk, 2020; Sari, 2019; Sari, Putra, and Sujarwoto, 2020), are:

1. Processing and developing the real potential of the village as the subject and object of business development;

2. Obtain a precise and permanent source of funding, allocated from state funds guaranteed by law;

3. It is a joint venture where the community can invest in each managed business unit and collaborate with other villages to develop business.

Collaboration, according to Zeho, Prabowo, Estiningtyas, Mahadiansar, and Sentanu (2020) are intended to deal with dynamic business environments and global competition by pooling skills, building teamwork and joint expertise, and pooling 
capital for customer-oriented businesses, requiring democratic leadership and information disclosure as characteristics of the new business world; d) Is a small business that utilizes local potential and raw materials, does not depend on imports, making VOEs not vulnerable to global economic fluctuations, due to exchange rates, trade between countries, and the world economic recession. Although based in rural areas, the development of VOE is ideally oriented towards the global market, which has been less of a concern in developing this business. According to Kotler and Armstrong (2010), a business cannot develop without a transparent market. Even businesses in villages should be globally integrated because they relate to one another (Marquardt and Reynolds, 1994).

The development of VOEs in Indonesia, which began in 2015, has not been profitable. Many VOEs do not operate at all. The 2018 National Statistics recorded 83,931 villages, and of these, only 22,000 villages $(26.21 \%)$ have formed VOEs; as many as 61,931 villages $(73.79 \%)$ have not been implemented. Even though the nominal allocation of village funds, among others, is to support the development of the Business Entity until 2019 reaches 257 trillion rupiahs. The rupiah value represents the total allocations for the last five years, namely 2015 (20.8 trillion), 2016 (47 trillion); In 2017 and 2018, each was 60 trillion, and in 2019, it was 72 trillion rupiahs. The funds are used for the construction of village roads along 195.2 thousand kilometres, 914 thousand meters bridges, 22,616 units of clean water connections; 2,201 mooring units, 14,957 units of Early Childhood Education; 4,004 units of Village Polyclinic; 19,485 units of clean water wells; 3,106 village markets; 103,405 village drainage and irrigation units; 10,964 units of Integrated Health Service Posts; and 1,338 units of village food barns apart from being designated for business development (Ministry of Finance of the Republic of Indonesia, 2019). The problems include:

1. Nationally, of the existing 22,000 units, 2,188 are not operating, and 1,670 units are operating but have not contributed to the village's original income.

2. Management is not transparent, not accountable, and does not involve villagers.

3. Not yet able to support the acceleration of people's economic development in the village through small and medium scale fisheries cultivation, post-harvest management, small and micro-industry, development of tourist villages through job creation, and reducing poverty in the village.

In West Java province, the Governor (Ridwan Kamil, 2019) said that 60 per cent of existing VOEs do not develop and die because of the inability to identify and choose the right market (Kompas.com, Wednesday 20/3/2019). In Pariaman (West Sumatra Province), only 32 VOEs units were formed from 50 existing villages, 19 active units, and 13 units with no reports (https://sumbar.Antaranews.com, March 2020); 4) has not been able to make a real contribution to local revenue. In Kolaka Regency (Southeast Sulawesi Province), they can only contribute 8 million rupiahs per year. In comparison, the village income and expenditure budget needs of 800,000,000 to 1.2 billion rupiahs per year or only $1.00 \%$ to $1.5 \%$ are met from VOEs profit 
(Community Empowerment Service Report, Kolaka Regency, 2019). This means that the village budget included in the development of VOEs has not had a significant effect on its contribution to the village's original income in Indonesia. The question is, what the VOEs development management model is? Why hasn't the VOEs development been successful? What are the determining factors?

\section{Literature Review}

The management model is often interpreted as a pattern or the way an organization manages its activities to develop with all its attributes (Berman, Wicks, Kotha, and Jones, 1999; Garel, 2013; Mwita, 2000; Savall, 2003). There are three management models: the subjective model, the ambiguity model, and the cultural value model. First, the subjective model is a management model controlled by the individual's behaviour as an actor in the management process. The organization's continuity depends on the ability of people to control and play a role in the organization according to the perceptions, knowledge, expertise, skills, abilities, and experiences of actors in planning, organizing resources, taking action, monitoring, and evaluating for organizational success. The focus of organizational development depends on the organization's members, shareholders, or interest groups. Management development depends on the understanding, interpretation, behaviour, and actions of the individual.

Postmodernist leadership in this model is developed according to the personal qualities and skills possessed in managing the organization and is not simply determined by the officials' target outcome and authority. The characteristic of postmodernism is that words do not always describe facts because every fact is not immediately discernible; there can be a variety of facts, each situation can be interpreted differently or have multiple interpretations depending on the person, and situations must be distinguished separately from their diversity. This model is relevant to global-oriented business development, which requires learning organizations and individuals (Marquardt and Reynolds, 1994; Örtenblad, 2004; Syam, Akib, Patonangi, and Guntur, 2018), building systems thinking in understanding every business problem, creating knowledge in action (Nonaka and Takeuchi, 1995) to seize opportunities and lead business markets.

Second, the ambiguity model is characterized by inconsistencies in management. The ambiguous model understands that organizations have technical problems in their work processes, not just understanding people. Organizations are fragmented, influenced by changes in technology and their environment, and driven by shared yet inconsistent values and goals. The linkages between groups are volatile and uncertain. Organizational structure is faced with the will of the team or committee, which often overlaps with one another. They determine how to deal with managing individually according to their duties, emphasizing individual participation in the management process. The organization does not bind participants; they are free to make choices and change from time to time. Changing environmental conditions due to changes in technology and the demands of markets and consumers make organizations must change (Tapscott, Ticoll, and Lowy, 2000). 
Management models like this are complex in making decisions in a structured and planned manner. The focus of the objectives is not clearly understood; the problems, solutions, and relationships between participants and essential choices are often confused. The ambiguous model of stress management under conditions of decentralization, because it provides a difficult to predict by organizations, gives birth to many decisions made by sub-units and individuals. Relevant leadership is a contingency, situational, adaptive style according to the conditions at hand. The weaknesses, among others, are that the specific objectives are not clear, take time to understand, and staff need to understand and explore what the leadership wants.

Third, the cultural model views values and ideologies as central to the organizational control. Individuals are united by agreed ideas and value choices and are influential in achieving goals. Everyone is required to understand the behaviour of other members. Norms and culture are born from habits shared and communicated in groups and are characterized by the use of symbols and rituals in action. The focus is on shared values, shared understanding, mutual trust, mutual understanding; differences are united by values and harmony in the organization and controlled by organizational culture. This model tends to be slow in facing market changes that are so fast and dynamic that according to Marquardt and Reynolds (1994), changes in the global market and environment due to the technological revolution, changes in work patterns and lifestyles as well as very drastically changing ways of interacting require business organizations to learn, be creative, creating knowledge (Choo and de Alvarenga Neto, 2010), innovating rapidly to exist (Nonaka and Takeuchi, 1995; Tapscott et al., 2000; Thurbin, 1998), especially in the millennial era today because of the indisputable demands of advances in communication and information technology.

The dimensions of healthy business development management include legality, provision of human resources (HR), organizational structure, organizational rules in the form of articles of association and bylaws, vision and mission, type of business and program determination, capital, production processes, and value chains, orientation, and marketing strategy, supervision, profitability, business performance, sustainability, and reporting are the focus of attention of good business management (Kotler and Armstrong, 2010). The success of business development is due to the existence of a transparent market, environmental factors in which the business operates in the form of a supportive political environment, the economy in the form of solid consumer income and purchasing power, beneficial socio-culture, technology, physical environment, demographics and laws that make it easy and fair.

Michael E. Porter in Argyres and McGahan (2002) mentions the ability to compete through creating more value than competitors, making businesses dominate the market. Businesses must apply skills, knowledge and be located in a robust market environment (King and McGrath, 2002), talented human resources in the creation of business knowledge (Nonaka and Takeuchi, 1995), intelligence, knowledge, and competence to build a company (Tuomi, 1999), business logic solid and professional management (Thurbin, 1998), organizing the potential and division of tasks in 
developing business regularly (Mintzberg, McCarthy, and Markides, 2000), mastery and use of technology for business (Drucker, 2006), as well as production technology support, technology to facilitate services, information technology and the use of digitalization as a potential business capital (Tapscott et al., 2000), adaptability in a changing environment (Gill, 2002), able to identify and take advantage of vast global opportunities without boundaries (Marquardt and Reynolds, 1994; Ohmae, 2000), understanding the needs, wants and tastes of consumers, maximizing organizational potential and competence. Individuals develop innovation in business, strong leadership in managing the business effectively (Hao and Yazdanifard, 2015), and leaders who can recognize, manage and develop talented people to maximize organizational performance (Kessler, 2008).

\section{Methodology}

This study uses a qualitative description approach (Campbell, 2014), a literature study (Mohr, 1999), and uses data from various reliable sources from government institutions in the form of official data and information on VOE management from several villages in Indonesia. More than one hundred villages spread across several regencies, districts within sub-districts representing the provinces in Indonesia studied, namely 35 villages on Java Island, 27 villages on Kalimantan Island, 32 villages on Sumatra Island, 45 villages on Sulawesi Island, and ten villages in West Papua. Based on the Central Statistics Agency (CSA) data, there were 83,931 villagelevel administrative areas in Indonesia in 2018.

This number consists of 75,436 villages (74,517 villages and 919 Nagari in West Sumatra), then 8,444 urban villages, and 51 units or transmigration settlement units (CSA, 2018). Observations were also made on the performance of the VOEs owned and developed in a number of these villages. Documents and information on VOEs performance are obtained from online media and statistical data, especially from the $\mathrm{CSA}$ at the central and regional levels (provinces and regencies and districts in Indonesia). Furthermore, several informants from interviews with key informants and secondary information obtained from interviews on social media support the need for study reports. Data and information are processed and analyzed following the interactive model stages (Miles, Huberman, and Saldaña, 2018), including data collection, data condensation, and verification/drawing conclusions.

\section{Results}

\subsection{VOEs Development Dimensions}

Legality: VOEs organizations are formal, legalized by village regulations agreed by the Village Consultative Body (VCB). The organizational structure and management are determined by the Village Head, consisting of three people, each chairman, secretary, and treasurer, acting the same. The legal basis for the formation and establishment of the VOE organization is uniformly valid nationally in all villages in Indonesia, regulated by a regulation of the Minister of Villages and Development of 
Disadvantaged Areas. The VOE formation mechanism is left to the village government, whose process involves the $\mathrm{VCB}$ and elements of the village community.

Table 1. VOEs Identity and Legality Format

\begin{tabular}{|c|c|c|}
\hline No. & Component /Identity & Information Required \\
\hline 1 & Identity of VOE & Name of VOE \\
\hline 2 & $\begin{array}{l}\text { Head office address and } \\
\text { place of operation }\end{array}$ & $\begin{array}{l}\text { Street name, Number ... (Neighborhood, Citizen Village) } \\
\text { District:.... Regency: .... Province: }\end{array}$ \\
\hline 3 & Time of Establishment & Day / Month/ Year \\
\hline 4 & $\begin{array}{l}\text { The legality of } \\
\text { Establishment Decree }\end{array}$ & Village Regulation Number, Year of VOE Establishment \\
\hline 5 & Management Team & $\begin{array}{l}\text { Village Head Decree / Year / Regulation Number concerning } \\
\text { VOE Management Team }\end{array}$ \\
\hline 6 & Management Structure & $\begin{array}{l}\text { Chairman (Name of Personnel); Secretary (Name of personnel); } \\
\text { Treasurer (Personnel name) }\end{array}$ \\
\hline 7 & $\begin{array}{l}\text { Type of Business / } \\
\text { Program }\end{array}$ & Production Business / Service Business, type of business unit \\
\hline 8 & Initial Capital/Fund & $\begin{array}{l}\text { a. Funds from the Village Government } \\
\text { b. Funds from the Community }\end{array}$ \\
\hline 9 & Growth $(\Delta \mathrm{A})$ & $\begin{array}{l}\text { Assets in the initial year of establishment (Ao); Assets end year } \\
\text { at evaluation) (At) } \\
\text { Growth = At - Ao }\end{array}$ \\
\hline
\end{tabular}

Source: Summarized from the regulations for developing VOEs in Indonesia, 2020.

In contrast to the development of rural small and medium enterprises in general, the development of VOEs was formed with a formal approach from the start, through central and regency government and village government regulations that stipulate legality, sources of capital from state funds, organizational management structure, programs and types of business, guidance, and supervision all arranged or consulted with the village government.

Business Capital and Management: The principal capital of VOE is from the participation of the village government and community funds. Village fund participation in the form of a) Grants or cooperation from the private sector, community socio-economic institutions, or donor agencies that are channelled into the Village Revenue and Expenditure Budget (VREB); b) Assistance from the central government, provincial governments, and regency and city governments; c) Village assets submitted to the Village Government Treasury are following applicable laws. Meanwhile, community fund participation comes from community savings, community savings which are included in business development.

Standard, administration, supervision, monitoring, reporting, and financial accountability of VOEs follow State financial management rules because there is an element of State finance. Business results or profits of VOEs include a) Business results, namely the results of transactions minus expenses and liabilities to other parties, as well as the depreciation of inventory items in one financial year; $b$ ) Distribution of VOEs business results based on Articles of Association and Bylaws. 
Managers and Responsibilities: The VOE organizational structure is regulated nationally through a Regulation of the Minister of Villages and Development of Disadvantaged Areas (Number 5 of 2015), consisting of advisors (ex officio village heads), operational executors, and supervisors. First, the advisor is obliged to a) Provide advice to the operations team in managing the business; b) Provide opinions on issues that are considered essential for VOEs management; c) Controlling the implementation of business activities. Meanwhile, the authorities are a) Requesting an explanation of the implementation of operations, including the problem of Village business management; b) Protect village businesses against things that can reduce business performance.

Second, executors are obliged to: a) Implement and develop VOEs into economic institutions, provide for the needs of the Village community and provide benefits; $b$ ) Exploring and utilizing business potential to increase original village income; c) Cooperating with economic institutions. Meanwhile, the authorities are: a) Preparing monthly financial reports of all business units; b) Make reports on the development of business units every month; c) Provide reports on the progress of VOEs business units to the Village community through village meetings at least twice a year. Operational executors appoint members of the management according to the business sector's capacity to take care of business records and administration and business operations. Requirements to become operational executors: a) Village communities have an entrepreneurial spirit; b) Has permanent domicile in the village for at least two years; c) Have a good personality, honesty, fairness, competence, and concern for Village economic enterprises; and d) Minimum education of public secondary school, equivalent; The executor is obliged to report the accountability for the management and management of the VOEs to the village head periodically.

Third, a village supervisory team, a village head, was formed together with the VCB. The composition of the supervisory team consists of a chairman, a vice-chairman who is also a member, a secretary who is also a member and a member. The period of service for supervisors is regulated in the organization's Articles of Association and Bylaws. Supervisors represent the community's interests in managing VOEs and are obliged to hold a general meeting to discuss Voe's performance at least once a year. The supervisor's authority is to hold a General Meeting for a) The election and appointment of management; b) Determining policies for developing business activities; c) Implementing monitoring and evaluation of operational performance.

Program and Type of Business: The VOE program is determined according to the vision and mission formulated since its establishment, stipulated in the organization's Articles of Association and Bylaws. The selection of VOE business types is carried out through the following stages: a) Identification of the type of business, assessment, or assessment; b) Observation and evaluation of opportunities and possible obstacles; c) Determination of the selected species; d) Activity planning; e) Structuring and selection stage; f) Operation, maintenance and development phase; g) Reporting and accountability. Based on local resources and available technology, VOEs develop various types of businesses, including service businesses for the needs of residents in 
the form of clean water (drinking water), village electricity businesses, village markets, rental of rice mills, transportation equipment, buildings, and party equipment.

Each region develops a business according to its regional potential. For example, VOEs in Padang Pariaman (West Sumatra) develops types of agricultural businesses, Batu Sangkar Regency (West Sumatra) manages markets, in Kutuh Village (Bali Province) and Ponggok Village, Klaten Regency (Central Java Province) develops tourism business in Sawahlunto (Province West Sumatra) develops a spice processing business, in Kolaka (Southeast Sulawesi Province) provides drinking water, a savings and loan business and a trading business for the community's basic needs.

The development of inter-village VOEs cooperation, including with other economic actors outside the village, can be carried out as long as it gets approval from the village government. The composition of shareholding is based on the nominal amount of assets and capital to calculate the amount of profit and loss borne by each party. In Pariaman (West Sumatra Province), the city government created joint VOEs, which the Pariaman City government legalized, and each included capital from city government assistance worth 50 million rupiahs per village.

Management Coaching: The pattern of guidance in developing VOE is carried out in a structured manner, namely:

1. The central government, through the Minister of Villages and Development of Disadvantaged Areas, establishes VOEs norms, standards, procedures, and criteria;

2. Governor (provincial level) disseminates technical guidance on management standards, procedures, and criteria and facilitates accelerated capital development and VOEs management guidance;

3. The Regent or Mayor (regency or city level) provides guidance, monitoring, and evaluation of the management and human resource development of VOEs managers;

4. The VCB shall supervise the performance of the village government in fostering the management of VOEs.

The Village Government is accountable for the guidance of VOEs to the VCB, which is conveyed through the Village Deliberation; e) The operational team reports the performance of business development to the Village Head, as the advisor and person in charge in the village.

Performance evaluation: The evaluator team determines to what extent the implementation of VOE is economically feasible or not. The losses experienced by VOEs are a burden on VOEs management. If the VOE cannot cover the loss with its assets and assets, it must be declared a loss through the Village Consultative Meeting. VOEs-owned business units that cannot cover losses with their assets and assets are declared bankrupt by the provisions in the statutory bankruptcy. The evaluation of 
the performance of the village head in coaching VOE is carried out using several other indicators:

1. The success of the village government in creating VOE, legally accompanied by its management, the inclusion of initial capital.

2. Business scale development according to VOE work program through additional capital participation support.

3. Increase the contribution of VOEs in supporting Village Original Income (VOI) through the use of profits.

Table 2. Summary of Management Model for VOEs Development in Indonesia

\begin{tabular}{ll}
\hline VOE Development Stages & Management Model \\
\hline The decision to establish VOE & $\begin{array}{l}\text { Ambiguous (central government) } \\
\text { Subjective (village government) }\end{array}$ \\
\hline The process for forming VOE & Village government subjective \\
\hline The legality of establishing VOE & $\begin{array}{l}\text { Subjective (central government and village } \\
\text { government) }\end{array}$ \\
\hline $\begin{array}{l}\text { Determination of the number of personnel } \\
\text { and personnel criteria }\end{array}$ & Central government subjective \\
\hline Determining who will be in charge & Cultural approach \\
\hline $\begin{array}{l}\text { Determination of the articles of association } \\
\text { and bylaws (vision and mission) }\end{array}$ & Village government subjective \\
\hline Determination of program/type of business & Village government subjective \\
\hline Funding source policy & Central government subjective \\
\hline $\begin{array}{l}\text { Nominal Amount of Equity Participation } \\
\text { from VREB }\end{array}$ & Village government subjective \\
\hline Business development orientation & Cultural approach \\
\hline Business management activities & Cultural approach \\
\hline $\begin{array}{l}\text { Establishment of a supervisory team } \\
\text { requirements and number of supervisory } \\
\text { members and division of supervisory tasks }\end{array}$ & Central government subjective \\
\hline Implementation of supervisory duties & Ambiguous / Inconsistent \\
\hline $\begin{array}{l}\text { VOE Performance Appraisal } \\
\text { Activity reporting }\end{array}$ & $\begin{array}{l}\text { Ambiguous / There is no uniform standard } \\
\text { yet }\end{array}$ \\
\hline $\begin{array}{l}\text { Source: Research results, } 2018-2019 . \\
\text { The central government and village } \\
\text { government subjective }\end{array}$ \\
\hline
\end{tabular}

Source: Research results, 2018-2019.

VOE Management Model: The national regulation by the Minister of Villages and Development of Disadvantaged and Underdeveloped Areas Number 5 of 2015 states, Villages can form VOE, meaning ambiguous. When using the term 'can,' every village does not have to develop a VOE. Based on this regulation, some villages have developed, but many villages have not yet formed VOE. The establishment of a VOE is an initiative of the village government and the village community by considering economic potential, natural resources, human resources, readiness for capital participation from the VREB. It is not wrong to make such a decision, because according to Iriani et al. (2020) that rural business development is not only approved 
or not by the village government but must consider the business potential and consider the potential of individuals and organizations to seize market opportunities. Such national regulations are characteristic of an ambiguous management model seen from the rules regarding the certainty of establishing VOE.

Finally, the establishment of VOE became a subjective decision from the village government. When the VOE was formed, the village government's efforts to maximize business could be made by building alliances with other villages (two or more villages). They formed a joint venture that was agreed upon by the village head, village consultative body, and community leaders. The village deliberation agreement is stated in a written report signed by the Head of the VCB and the Village Head. According to experts (Berman et al., 1999; Garel, 2013; Mwita, 2000; Savall, 2003), this pattern is called a cultural management model that prioritizes values, collective decisions, respects the opinions of other parties, and involves related parties in making decisions to develop VOE. According to Robbins, Judge, and Millett (2015), this method benefits organizations because they involve interested people in the decision-making process. A summary of the results of the identification of the management model for VOEs development in Indonesia is presented in Table 2.

The stages of developing VOEs seen from the management model approach are described as follows:

1) The decision to form VOE is ambiguous because there are two governing powers, namely the subjectivity of the central government and the village government;

2) The process of establishing VOE is the authority or decision of the village government to form or not form VOE because it is subjective;

3) The legality of establishment is determined subjectively by the central government and village governments;

4) Determination of the number of personnel and criteria for VOE management personnel is subjective and regulated by the government nationally;

5) Determining who becomes the management or executor of $\mathrm{VOE}$ management using a cultural approach model;

6) Determining the Articles of Association and Bylaws, determining the program in the form of the type of business and the number of business units is the subjective decisions of the village government by taking into account the business opportunities and potential;

7) The policy regarding the source of capital is a subjective decision by the central government nationally. In contrast, the nominal amount of capital participation from the VREB for the development of VOE is the authority and subjective decision of the district government and village government;

8) The orientation of VOE business development and management activities uses a cultural approach, where the joint manager of the village government and supervisors develops a business in a dialogical manner which is marked by joint decision making, as recommended in the stipulations of its formation, but in fact, 
there are cases where the village head develops VOEs without coordinating with stakeholders;

9) The formation of the supervisory team, the requirements and number of supervisory members, and the division of supervisory tasks are determined nationally and become a subjective decision of the central government;

10) The implementation of the supervisory duties and performance appraisal of VOE is ambiguous because there are no clear and measurable indicators that are made to measure the success of its business development, only narrative information. However, business-wise, the VOE is successful in terms of the level of profit earned;

11) Reporting VOEs activities and developments is made subjectively by the central government, but the practice is ambiguous in the village because there is a closure in the business management process by the manager and the village head.

\subsection{Discussion}

To develop a business professionally and achieve maximum profit, VOEs implementers must be competent, that is, be able to develop a business professionally. According to Iriani et al. (2020), rural business management can only run and be profitable if management understands good business management. The characteristics of individuals who master the business can assess future business potentials, develop a business, and raise capital continuously for business progress. A good manager can increase business income, promote business by increasing volume, increase capital, and increase the type of business. They were determining the type of business, considering the potential and natural resources, market opportunities (Kotler and Armstrong, 2010), availability of capital, and meeting the needs of citizens. According to Muluk (2020), a good VOE development strategy is carried out in stages; considering local conditions, creative ideas and innovations are needed to grab market share. The pattern is carried out through socialization and learning about VOE (Mania et al., 2020), implementation of deliberations regarding business development prospects (Papilaya, Soisa, and Akib, 2015; Srirejeki, 2018).

Establishment of a VOE by selecting one or two prospective business types as a first step according to financial conditions and market opportunities (Iriani et al., 2020); Business feasibility analysis (Srirejeki, 2018); Develop business diversification, market expansion, increase business capacity (Iriani et al., 2020; Sari, 2019); The development of cooperation, strategic partnerships and inter-village collaboration in developing joint ventures have yet to be carried out, even though the regulations allow for that.

The selection of types of businesses that are only oriented towards meeting the local market, in the form of groceries, selling stationery, necessities developed by VOE, is currently slow to develop. According to Muluk (2020), apart from paying attention to local needs, reaching the global market for sustainable profit is an opportunity. To achieve large and sustainable profits, it must enter a broad market or export product market. It is impossible to achieve significant profits by only developing businesses to meet the needs of residents because the local market has minimal potential, and the 
purchasing power of the community is limited (Argyres and McGahan, 2002; Berman et al., 1999; Djafar, Syam, Raharjo, Abdussamad, and Akib, 2019; Drucker, 2006; Garel, 2013). Several types of businesses that have been developed to meet local needs and are also export-oriented are establishing ice block factories to support export-oriented fishery businesses, agricultural product processing industries, provision of agricultural production facilities, furniture production businesses. Local needs-oriented businesses form micro-business loans for Village communities (Mania et al., 2020). The pattern uses a cultural management approach model, which is jointly managed, making decisions on choosing the type of business following the norms and wishes of all related parties in the village.

The development of VOEs in Indonesia has not been successful according to the central government or according to public assessments. Its success is not only seen in terms of profitability, as is the measure of business performance in general. VOE is a village government effort where the achievement of the village head's vision and mission is the criterion for assessing its success (Kessler, 2008; Nonaka and Takeuchi, 1995; Srirejeki, 2018; Thurbin, 1998; Tuomi, 1999).

Therefore, the profit contribution to the VOI is an indicator of success according to the village government, not just a significant profit. Its success is measured by the ability to earn profits to support VREB revenue, the portion of which is determined by each village, in addition to business development and operational costs. So far, this contribution has been very minimal, not by the number of village funds included as capital in the development of VOE. Also, the success of VOEs, according to Iriani et al. (2020), uses the criteria of performance achievement, future program relevance, the accuracy of resource allocation, and management processes. The evaluation results by the central government found that the development of VOEs had not been successful, either from the number of formed business activities or the profits obtained. The evaluation results show several aspects that cause the failure of VOE development.

As a community empowerment-based "government business," the measure of the success of VOE, according to experts (Iriani et al., 2020; Mania et al., 2020; Muluk, 2020; Srirejeki, 2018), does use not only financial indicators but also uses the following indicators, namely: a) To what extent planning and determining programs are by local needs and have broad market prospects; b) The implementation of the program is following the plan and can make adjustments to the problems faced; c) The extent to which the stipulated program can be realized, including the legality of VOE, selection of business types, capital participation, improved governance, citizen participation, including financial performance. Financially, the extent to which the business is developed provides profit; the business volume grows, operational activities increase, and the contribution to VOI increases.

Mwita (2000) states that measuring performance is not only assessing results but evaluating performance planning, the process of achieving performance, and the achievement of performance targets. In VOE development that has been running for 
five years, the performance target has the determining factors for the success of a VOE in running a business and getting profit as a rural business depends on several factors. Smith and Akib (2015) state that the determinants of successful program implementation, including business program development, are mentioned by Kotler and Armstrong (2010) as organizational factors and environmental factors. Organizational factors include human resources, not just quantity but knowledge, skills, discipline, work ethos, and commitment. Business managers should have managerial knowledge to determine the types of businesses that have market opportunities, master production techniques, and manage and take advantage of opportunities. Kessler (2008) states that the fulfilment of human resource needs in rural businesses must be supported by training and fostering financial management, in addition to work ethics and commitment. A low work ethic makes VOEs less developed; on the other hand, a high work ethic makes a business successful.

The main problem in developing VOE is limited human resources. Nonaka and Takeuchi (1995) emphasize that HR is capable of creating business knowledge, intelligence, and competence to build a company as essential capital, apart from needing business sense (Tuomi, 1999), strong business instincts, and professional management (Thurbin, 1998). Organizing the potential and division of tasks in developing a business regularly (Mintzberg et al., 2000) is also a determinant of business progress, which is not yet owned in VOEs development. Therefore, to develop VOE that is advanced in the future, it is necessary to provide quality human resources to identify and take advantage of the unlimited global market opportunities that must be achieved to achieve the maximum benefit (Ohmae, 2000). According to Marquardt and Reynolds (1994), another ability is the ability to develop themselves as individual learners to overcome obstacles and solutions in business development. Leaders should understand consumers' needs, wants, and tastes (Cloke and Goldsmith, 2002), maximize organizational potential and individual competencies to develop innovation and creativity in business (Hamel, 2001; Ogar and Edor, 2021).

Creative, innovative leadership and providing space for employees to find new ideas, new opportunities, new ways of working, and new products are the keys to business success (Bake, 2004; Choo and de Alvarenga Neto, 2010; Hao and Yazdanifard, 2015), not a cultural approach alone. According to Robbins et al. (2015), innovative leadership is the key to organizational success by applying organizational values and norms. To achieve organizational progress, every business target must be embedded through solid leadership.

According to experts (Gill, 2002; Hao and Yazdanifard, 2015), strong leadership can identify, manage, and develop talented people to maximize organizational performance and determine business development success. Technological support and work equipment support an increase in the quantity and quality of products to increase sales value and income. One of the weak points of developing VOE is that it has not made technology tools, facilities, and media to produce production or utilize technology as a business commodity. 
Whereas according to Drucker (2006), the mastery and use of technology for business in the form of production technology, technology to facilitate after-sales service, and information technology make business exist in a technology-intensive world. Even modern businesses, including rural areas, have sufficient access to information technology to facilitate digital use as a potential capital in developing a business professionally and sustainably (Tapscott et al., 2000). Organizational culture in the form of fair treatment, respect for creativity, and innovation for business progress are norms that benefit business development. A flexible culture makes it easier for employees to adapt to a work environment and change business practices (Choo and de Alvarenga Neto, 2010; Syam et al., 2018).

Rapid response and adaptive culture are the capital in responding to fast-changing markets to win the business competition. Giving rewards and punishments to every employee is a culture that supports positive performance. According to Marquardt and Reynolds (1994), it is necessary to have a learning culture, namely a team of learners and individual learners, to lead change in organizations to continue to exist in competition. Discipline culture in the form of obedience, obedience, loyalty, work order in realizing the program is the key to success. Estipona (2009) emphasizes the culture relevant to the management process as the key to success which was found to be a critical success factor in business development. Second, factors outside the organization. Several factors outside the organization that determine the success of business development are transparent markets (Kotler and Armstrong (2010), environmental factors in which the business operates, namely a supportive political environment, economic factors in the form of solid consumer purchasing power, beneficial socio-culture, technology, physical environment, demographics and laws that make it easy and fair.

Village government intervention and subjectivity in determining the management of business activities involves an elite group of village communities who ignore managerial competence as elements that weaken the performance of VOE. The availability of raw materials needed by the managed processing industry is an inhibiting factor, making it difficult for businesses to develop. Economic conditions in the form of income and purchasing power of local communities are inhibiting factors for the development of VOE. The social aspect of society in the form of cooperation in advancing VOE, which is manifested through the habit of shopping at VOE stores, is a behavior that benefits its development.

Support from the central government and village governments in financing production activities, regulation, and guarantee of capital are supporting factors so that there are no obstacles to capital as long as the business being developed is profitable. Legality and legal guarantees are the capital to build networks and cooperation with outsiders in developing a business together. Development cooperation can be carried out through a collaborative approach providing mutual capital, skills, and expertise (Rengifurwarin, Akib, Jasruddin, and Salam, 2018) to develop extensive, prospective, cross-regional businesses whose products have the potential to export to get maximum profit. 
Integrated management with total quality management (TQM) approach (Cloke and Goldsmith, 1997) is the key to business success. In the TQM concept, business development is a system whose success depends on the quality and quantity of guaranteed raw material sources, correct production processes according to standards, accountable and transparent financial management. A guaranteed and sustainable products market is a prerequisite for success in business development, including rural businesses. Things like that have not been done, so the development of VOEs in Indonesia has not been successful. Therefore, to exist, every business, including VOEs, must be able to create more value for competitive advantage and dominate the market (Porter, 1998), a quality company, controls costs and moves quickly for competitive advantage (Slater, 1999), according to King and McGrath (2002) must be based on the possession of skills, knowledge, and competencies in developing a business success of business development.

The success of sustainable business development must also be built through a learning culture, creating knowledge in the organization in a sustainable manner to form creative and innovative individuals and organizations in responding to market needs in a rapidly developing revolutionary manner (Akib, 2005). Rapid changes today are the impact of advances in communication and information technology that have penetrated remote villages and formed a millennial lifestyle that relies on the power of online business networks.

Amid a millennial society in a COVID-19 pandemic condition and after entering the era of the new average local economy (NENOLE), according to Cahaya, Akib, Said, Mustari, and Yahyaddin (2019), business development should ideally no longer use a cultural management model that seems slow in responding to market changes. It needs a sophisticated management model to scramble for opportunities to gain profits quickly, which requires faster decisions and actions while still providing more value than competitors to win the competition in a global market without borders. If this is not the case, the ambition of the Indonesian government to develop VOEs funded by state funds through the VREB will only be a place to waste public money, waste state money, and even become a new nest of corruption for the village elite. This can be detrimental to the state and burden the village budget, which should be used to build more profitable facilities to meet the needs of the people in the village.

\section{Conclusions and Recommendations}

The VOE development management model tends to be ambiguous, subjective and applies a cultural approach to specific activities. The process describes a subjective management model in decisions to establish VOE at the village level. The government regulates the legality of the establishment, determining the number and criteria of personnel, the stipulation of statutes and bylaws, policies for capital participation, and the establishment of a supervisory team, and regulation of the rights and responsibilities of supervisors and financial reporting. The granting of authority to establish VOEs from the central government to village governments is ambiguous, indecisive, including supervision, sanctions, and evaluation of VOE performance. 
The determination of bankruptcy criteria is very loose and not strictly regulated. In determining the management, implementation of management, business development orientation, and VOE management activities tend to use a cultural approach.

Organizational factors determine the success of VOE development in the form of availability of quality human resources, leadership, production technology support, organizational culture, financial governance processes, institutional arrangements. Meanwhile, contextual/environmental factors are in the form of government intervention and subjectivity, availability of raw materials, production technology, market accessibility and opportunities, income and purchasing power of the community, and social conditions in the form of cooperative behaviour of community members advancing rural businesses.

Facing the millennial community in the conditions of the COVID-19 pandemic and afterwards whose the latest information technology developments influence lifestyle and consumption patterns, the development of VOE should ideally no longer rely on cultural management models that seem slow in responding to change but a management model that is easily adaptable in scrambling for opportunities and gain profits quickly, able to make decisions and actions faster while still providing more value than competitors to win the competition in the global market that has spread to remote villages in Indonesia.

\section{References:}

Abakare, C.O. 2021. The Revival of Virtue Ethics As an Ethical View. PINISI Discretion Review, 4(2), 285-298. https://doi.org/10.26858/pdr.v4i2.20003.

Akib, H. 2005. Kreativitas Dalam Organisasi. Jakarta, Indonesia: Ilmu Administrasi FISIP Universitas Indonesia.

Argyres, N., McGahan, A.M. 2002. An interview with Michael Porter. Academy of Management Perspectives, 16(2), 43-52. https://doi.org/10.5465/ame.2002.7173495.

Badan Pusat Statistik. 2018. Jumlah Desa di Indonesia. Jakarta, Indonesia.

Bake, J. 2004. Pendekatan 4 P Kreatif: Pengertian dan Model Pengukuran Kreati-vitas dan Inovasi. Usahawan, 4, 51-56.

Berman, S.L., Wicks, A.C., Kotha, S., Jones, T.M. 1999. Does stakeholder orientation matter? The relationship between stakeholder management models and firm financial performance. Academy of Management Journal, 42(5), 488-506. https://doi.org/10.5465/256972.

Cahaya, A., Akib, H., Said, F., Mustari, Yahyaddin, M. 2019. Snapshot of the SocioEconomic Life of Fishermen Community Based on Social Entrepreneurship in Bone Regency, Indonesia. Academy of Entrepreneurship Journal, 25(1).

Campbell, S. 2014. What is qualitative research? Clinical Laboratory Science, 27(1), 3.

Choo, C.W., de Alvarenga Neto, R.C.D. 2010. Beyond the ba: managing enabling contexts in knowledge organizations. Journal of Knowledge Management.

Cloke, K., Goldsmith, J. 2002. The end of management. San Francisco: Jossey-Bass.

Directorate General of Rural Areas Development, Ministry of Villages, Disadvantaged Regions, and T. of the R. of I. 2017. Technical Guidelines; Procedure for Establishment, Management and Management, and Dissolution of Joint Village- 
Owned Enterprises.

Djafar, R., Syam, H., Raharjo, P., Abdussamad, J., Akib, H. 2019. Reconstruction of Poverty Reduction Strategy Model Based on Community Empowerment Programs. Academy of Entrepreneurship Journal, 25(2), 1-10.

Drucker, P.F. 2006. Classic Drucker: essential wisdom of Peter Drucker from the pages of Harvard Business Review. Harvard Business Press.

Eka, P.D. 2020. The Effect of Leadership and Motivation on Organizational Commitment at PT. Indo Perkasa Indonesia in Tangerang. PINISI Discretion Review, 1(2), 73 80. https://doi.org/10.26858/pdr.v1i2.13047

Garel, G. 2013. History of project management models: From pre-models to the standard models. International Journal of Project Management, 31(5), 663-669. https://doi.org/10.1016/j.ijproman.2012.12.011.

Gill, R. 2002. Change management--or change leadership? Journal of Change Management, 3(4), 307-318. https://doi.org/10.1080/714023845.

Hamel, G. 2001. Leading the revolution:: an interview with Gary Hamel. Strategy \& Leadership. https://doi.org/10.1108/10878570110367141.

Hao, M.J., Yazdanifard, R. 2015. How effective leadership can facilitate change in organizations through improvement and innovation. Global Journal of Management and Business Research, 15(9).

Iriani, S.S., Andjarwati, A.L., Rahman, Z. 2020. Performance Optimization of VillageOwned Enterprises Through Business Management Training. In International Joint Conference on Arts and Humanities (IJCAH 2020), 1368-1373. Atlantis Press. https://doi.org/10.2991/assehr.k.201201.231.

Kessler, R. 2008. Competency-based performance reviews: How to perform employee evaluations the Fortune 500 way. Red Wheel/Weiser.

King, K., McGrath, S. 2002. Globalisation, enterprise and knowledge: Education, training and development in Africa. Symposium Books Ltd.

Kotler, P., Armstrong, G. 2010. Principles of marketing. Pearson education.

Mania, L., Arasb, M., Hidayatc, Z. 2020. Social Capital and Failure in Village-Owned Enterprises: A Case Study of Cangkudu Village, Balaraja District, BantenIndonesia. Social Capital, 13(7), 405-415.

Marquardt, M.J., Reynolds, A. 1994. The global learning organization. McGraw-Hill.

Menteri Keuangan Republik Indonesia. 2019. Perkembangan Badan Usaha Milik Desa.

Miles, M.B., Huberman, A.M., Saldaña, J. 2018. Qualitative data analysis: A methods sourcebook. Sage publications.

Ministry of Home Affairs Republik Indonesia. 2014. Law of the Republic of Indonesia Number 6 of 2014 concerning Village.

Mintzberg, H., McCarthy, D.J., Markides, C. 2000. View from the Top: Henry Mintzberg on Strategy and Management [and Commentary]. The Academy of Management Executive (1993-2005), 31-42. Retrieved from: https://www.jstor.org/stable/4165656?seq=1.

Muluk, M.R.K. 2020. Balanced Coopetition in the Establishment of a Village-Owned Enterprise. In 2nd Annual International Conference on Business and Public Administration (AICoBPA 2019), 260-267. Atlantis Press. https://doi.org/10.2991/aebmr.k.201116.051.

Mwita, J.I. 2000. Performance management model. International Journal of Public Sector Management, 13(1), 19-37. https://doi.org/10.1108/09513550010334461.

Nonaka, I., Takeuchi, H. 1995. The knowledge-creating company: How Japanese companies create the dynamics of innovation. Oxford university press.

Ogar, T.E., Edor, E.J. 2021. Creative Cultural Synergy: Towards the Africa of the Future. 
PINISI Discretion Review, 4(1), 135-150. https://doi.org/10.26858/pdr.v4i1.152.

Ohmae, K. 2000. The invisible continent: Four strategic imperatives of the new economy. Nicholas Brealey.

Örtenblad, A. 2004. The learning organization: towards an integrated model. The Learning Organization, 11(2). https://doi.org/10.1108/09696470410521592.

Papilaya, J., Soisa, T.R., Akib, H. 2015. The influence of implementing the strategic policy in creating business climate, business environment and providing support facilities towards business empowerment on small-medium craft enterprises in Ambon Indonesia. International Review of Management and Marketing, 5(2). Retrieved from: http://econjournals.com/index.php/irmm/article/view/1160.

Rengifurwarin, Z.A., Akib, A.H., Jasruddin, U.N.M., Salam, R. 2018. Snapshot of Public Service Quality in the Center For Integrated Business Service (CIBS), Cooperative Micro Small and Medium Enterprises (CMSME), Maluku Province, Indonesia. Journal of Entrepreneurship Education, 21(3), 1-12.

Ridlwan, Z. 2014. Urgensi BUMDes dalam Pembangunan Perekonomian Desa. Fiat Justicia Jurnal Ilmu Hukum Fakultas Hukum Universitas Lampung, 8(3), 424-440. Retrieved from: http://repository.lppm.unila.ac.id/13935/1/2014 07 Urgensi BUMDes dalam Pembangunan Perekonomian Desa.pdf.

Robbins, S.P., Judge, T.A., Millett, B. 2015. OB: the essentials. Pearson Higher Education.

Sari, Y.P. 2019. Measuring the Financial Performance of Village Owned Enterprises (VOEs). JPAS (Journal of Public Administration Studies), 4(1), 14-18. https://doi.org/10.21776/ub.jpas.2019.004.01.3.

Sari, Y.P., Putra, F., Sujarwoto, S. 2020. Financial Performance of Village-Owned Enterprises (VOEs): Case in Blitar Regency, East Java, Indonesia. JPAS (Journal of Public Administration Studies), 5(2), 72-78.

Savall, H. 2003. An updated presentation of the socio-economic management model. Journal of Organizational Change Management, 16(1). https: doi/10.1108/09534810310459756.

Smith, A., Akib, H. 2015. The Implementation Effectiveness of Trash Management in Ambon, Maluku: The Influence of Socialization, Coordination and Control to the Effectiveness of Trash Management. International Journal of Public Administration, 38, 683-688. https://doi.org/10.1080/01900692.2014.908214.

Srirejeki, K. 2018. Empowering the role of village owned enterprises (BUMDes) for rural development: case of Indonesia. Jurnal Akuntansi, Manajemen Dan Ekonomi, 20(1), 5-10. Retrieved from: http://jos.unsoed.ac.id/index.php/jame/article/view/1018.

Syam, H., Akib, H., Patonangi, A.A., Guntur, M. 2018. Principal Entrepreneurship Competence Based on Creativity and Innovation at the Context of Learning Organizations in Indonesia. Journal of Entrepreneurship Education, 21(3), 1-13.

Tapscott, D., Ticoll, D., Lowy, A. 2000. Digital Capital: Harnessing the power of business webs. Ubiquity, 3. https://doi.org/10.1145/336228.336231.

Thurbin, P.J. 1998. The Influential Strategist: Using the power of paradox in strategic thinking. Financial Times Management.

Tuomi, I. 1999. Organizing for strategic knowledge creation. Corporate Knowledge: Theory and Practice of Intelligent Organizations. Retrieved from: Http://Www. Jrc. Es/ Tuomiil/Articles/OrganizingForStrategicKnowledgeCreationCh14. Pdf.

Zeho, F.H., Prabowo, A., Estiningtyas, R.A., Mahadiansar, M., Sentanu, I.G. E.P.S. 2020. Stakeholder collaboration to support accountability in village fund management and rural development. J of Socioeconomics and Development, 3(2), 89-100. 